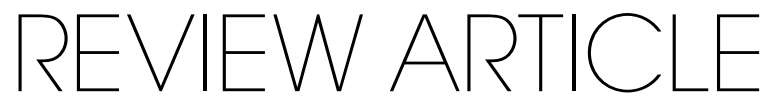

\title{
Treating PMP22 gene duplication-related Charcot-Marie-Tooth disease: the past, the present and the future
}

\author{
SUZAN BOUTARY, ANDONI ECHANIZ-LAGUNA, DAVID ADAMS, JULIEN LOISEL-DUWATTEZ, \\ MICHAEL SCHUMACHER, CHARBEL MASSAAD, and LILIANE MASSAAD-MASSADE
}

\author{
LE KREMLIN-BICÊTRE AND PARIS FRANCE
}

\begin{abstract}
Charcot-Marie-Tooth (CMT) disease is the most frequent inherited neuropathy, affecting $1 / 1500$ to $1 / 10000$. CMT1A represents $60 \%-70 \%$ of all CMT and is caused by a duplication on chromosome 17p11.2 leading to an overexpression of the Peripheral Myelin Protein 22 (PMP22). PMP22 gene is under tight regulation and small changes in its expression influences myelination and affect motor and sensory functions. To date, CMTlA treatment is symptomatic and classic pharmacological options have been disappointing. Here, we review the past, present, and future treatment options for CMT1A, with a special emphasis on the highly promising potential of PMP22-targeted small interfering RNA and antisense oligonucleotides. (Translational Research 2020; 000:1-12)
\end{abstract}

\begin{abstract}
Abbreviations: Peripheral Nervous System = PNS; Charcot-Marie-Tooth $=$ CMT; Human Peripheral Myelin Protein 22 gene $(P M P 22)$ protein = PMP22; Rodent Peripheral Myelin Protein 22 gene = Pmp22; Human Myelin Protein Zero = $(M P Z)$; and Myelin Basic Protein $=(M B P)$ genes; Guillain-Barré syndrome = GBS; Chronic Inflammatory Demyelinating Polyradiculo-Neuropathy = CIDP; Charcot-Marie-tooth 1A = CMT1A; Motor Nerve Conduction Velocity = MNCV; Compound Muscle Action Potential = CMAP; Hereditary Neuropathy with Liability to Pressure Palsies = HNPP; L1 cell adhesion molecule = (LICAM); and nerve growth factor receptor = (NGFR); Neurotrophin-3 = NT-3; Adeno-Associated Viruses = AAV; Charcot-Marie-Tooth Neuropathy Score = CMTNS; Overall Neuropathy Limitations Scale = ONLS; RNA interference = RNAi; Small interfering RNA = siRNA; Hereditary Transthyretin Amyloidosis = hATTR; Transthyretin $=$ TTR; Antisense Oligonucleotides = ASO; Heat Shock Proteins = HSP
\end{abstract}

\section{INTRODUCTION}

Disorders of the peripheral nervous system (PNS) affect $2.5 \%$ of the population. ${ }^{1}$ The glial cells of the PNS, known as Schwann cells, are responsible for myelination. They were discovered in the mid-nineteenth century by Theodore Schwann. ${ }^{2}$ Their main functions are to separate axons and to produce the myelin sheath that allows saltatory conduction of nerve impulses. ${ }^{3}$ Several diseases affecting PNS myelin have

From the U 1195, INSERM and Paris-Saclay University, Le Kremlin-Bicêtre, France; Neurology Department, AP-HP, Paris-Saclay Universityand French Referent Center for Familial Amyloid Polyneuropathy and Other Rare Peripheral Neuropathies (CRMR-NNERF), Bicêtre Hospital, Le Kremlin-Bicêtre, France; Faculty of Basic and Biomedical Sciences, Paris Descartes University, INSERM UMRS 1124, Paris, France.

Submitted for Publication March 23, 2020; received submitted July 2, 2020; accepted for publication July 15, 2020.

Reprint requests: LilianeMassade, U 1195, INSERM and Université Paris-Sud and Université Paris-Saclay, 94276 Le Kremlin-Bicêtre, France. E-mail address: liliane.massade@inserm.fr.

1931-5244/\$ - see front matter

(c) 2020 Elsevier Inc. All rights reserved.

https://doi.org/10.1016/j.trs1.2020.07.006 
been described, including (1) peripheral nerve trauma, (2) autoimmune polyneuropathies such as GuillainBarré Syndrome, ${ }^{5}$ chronic inflammatory demyelinating polyradiculo-neuropathy, ${ }^{6}$ and (3) inherited demyelinating sensory and motor neuropathies, including Charcot-Marie-Tooth disease (CMT). ${ }^{7}$

In this review, we will focus on CMT, the most frequent inherited diseases of the PNS with a prevalence of $1 / 1500$ to $1 / 10000$ worldwide. ${ }^{8-11}$ CMT are progressive neuromuscular disorders characterized by degeneration of the peripheral nerves leading to muscle atrophy, weakness in the distal limbs, absence of deep tendon reflexes, and osteoarticular deformations such as pescavus. In certain cases, wheelchair is needed. ${ }^{12}$ Although disease onset ranges from childhood to late adolescence, several forms of CMT may appear in adults and the severity of the symptoms differs between patients. ${ }^{9,10}$ It is noteworthy, that phenotypic variations of CMT are observed both in members of the same and different families. ${ }^{13}$

CMT is classified into 5 types depending on the mode of inheritance, the pathophysiology and causative genes involved ${ }^{14}$ (Table I). More than 90 genes comprising over 1000 rearrangements cause $\mathrm{CMT}^{9,15}$ and contributed to the phenotypic heterogeneity. CMT1 is the autosomal dominant demyelinating form that accounts for $50 \%-80 \%$ of all CMT cases. ${ }^{14}$ It is characterized by reduced motor nerve conduction velocity (MNCV) of less than $38 \mathrm{~m} / \mathrm{s}$, diminished muscle stretch reflexes and formation of onion bulbs. ${ }^{14,16}$ CMT2, represents $10 \%-15 \%$ of CMT, is the autosomal dominant or recessive axonal form that shows normal MNCVs $>45 \mathrm{~m} / \mathrm{s}$, decreased compound muscle action potential (CMAP) amplitude and reduced muscle stretch reflexes. ${ }^{8,17}$ CMT4, frequent in countries with high consanguinity, is the autosomal recessive demyelinating form and CMTX is the X-linked form that accounts for $10 \%-15 \%$ of all CMT cases. ${ }^{18,19}$ Interestingly, it has been found that several genes responsible for CMT are also involved in other neurological and neuromuscular disorders such as myopathy, spastic paraplegia, and motor neuron disorders that share common pathophysiological pathways. ${ }^{20}$ Recently, 4 genes were acknowledged as the main cause of the majority of the CMT cases: PMP22, myelin protein zero (MPZ), gap junction beta-1 protein $(G J B 1)$ and Mitofusin 2 $(M F N 2)^{8,14}$ and further knowledge about these genes is needed to understand the pathology of each subtype and facilitate the discovery of new treatment strategies. Moreover, it has been speculated that some gene modifiers play an important role in the heterogeneity of the disease. $^{21-24}$

Herein, we address the most frequent type, CMT1A, from drug treatment to PMP22 gene inhibition and highlight the most recent therapeutic innovations that open new avenues for the treatment of CMT1A patients.

\section{PERIPHERAL MYELIN PROTEIN: PHYSIOLOGICAL ROLE AND DISORDERS}

PMP22 is a $22 \mathrm{kDa}$ glycoprotein of 160 amino acids produced by Schwann cells. $^{25}$ It was identified in Schwann cells and the fibroblasts. ${ }^{26,27}$ Later, PMP22 gene was reported to be also expressed in the intestines, lungs and heart. ${ }^{28,29}$ The PMP22 gene has 2 promoters that lead to translation of 2 transcripts containing

Table I. Classification of CMT disease. The classification is done according to the inheritance and pathophysiological trends and examples of causative genes

\begin{tabular}{|c|c|c|c|}
\hline Type & Inheritance & Pathophysiology & Examples of causative genes \\
\hline $\mathrm{CMT1}$ & Autosomal dominant & Demyelinating $\mathrm{NCV}<38 \mathrm{~m} / \mathrm{s}$ & $\begin{array}{l}\text { PMP22, PO, LITAF, EGR2, NEFL, } \\
\text { FBLN5 }\end{array}$ \\
\hline \multirow[t]{2}{*}{ CMT2 } & Autosomal dominant & Axonal NCV $>45 \mathrm{~m} / \mathrm{s}$ & $\begin{array}{l}\text { MFN2, RAB7, TRPV4, PO, GDAP1, } \\
\text { HSPB8, DNM2, LRSAM1, } \\
\text { MT-ATP6, MARS, HARS }\end{array}$ \\
\hline & Autosomal recessive & & $\begin{array}{l}\text { LMNA, MED 25, GDAP1, MFN2, } \\
\text { NEFL, TRIM2 }\end{array}$ \\
\hline CMT4 & Autosomal recessive & Demyelinating NCV $<38 \mathrm{~m} / \mathrm{s}$ & $\begin{array}{l}\text { GDAP1, MTMR2, MTMR13, } \\
\text { EGR2, SBF1, NDRG1, FIG4, } \\
\text { SURF1, PRX, HK1 }\end{array}$ \\
\hline CMTX & X-Linked & Axonal NCV $>45 \mathrm{~m} / \mathrm{s}$ & GJB1, PRPS1, PDK3 \\
\hline $\begin{array}{l}\text { RI-CMT(Recessive } \\
\text { intermediate CMT) }\end{array}$ & Autosomal recessive & Intermediate $38<\mathrm{NCV}<45 \mathrm{~m} / \mathrm{s}$ & GDAPl, KARS, COX6A1 \\
\hline $\begin{array}{l}\text { DI-CMT (Dominant } \\
\text { intermediate CMT) }\end{array}$ & Autosomal dominant & Intermediate $38<\mathrm{NCV}<45 \mathrm{~m} / \mathrm{s}$ & DNM2, YARS, MPZ, IFN2, GNB4 \\
\hline
\end{tabular}


different noncoding exons, $1 \mathrm{~A}$ and $1 \mathrm{~B}$, which makes it tissue-specific and highly regulated. ${ }^{30,31}$ Promoter one that generates exon $1 \mathrm{~A}$ transcripts is active in myelinating Schwann while, promoter two and exon 1B transcripts are is expressed in tissues that do not produce myelin. $^{30}$

$P M P 22$ expression is regulated at the gene level as well as at the step of protein synthesis and translocation. In the peripheral nervous system, PMP22 comprises $2 \%-5 \%$ of the total myelin proteins and is located in the compact region of the myelin sheath. ${ }^{25}$ The majority of PMP22 protein is degraded in the endoplasmic reticulum, while only few proteins are glycosylated and reach the Golgi apparatus. ${ }^{32}$

$P M P 22$ has an essential role in myelination in the PNS but its biological functions are not clear yet. Proper folding and regulation of PMP22 is required for the normal function of myelinating Schwann cells. Evidence was shown that $P M P 22$ promote the organization of membrane ultrastructure in compact myelin. ${ }^{33}$ Moreover, it was documented that PMP22 plays a key role in the maintenance of cholesterol homeostasis in Schwann cells. PMP22 interacts with the cholesterol efflux regulatory protein ABCA1 to regulate lipid metabolism and cholesterol trafficking. ${ }^{34}$ Other than its role in the formation of myelin, studies have shown that $P M P 22$ is involved in different cellular functions such as adhesion and cell proliferation since it was first discovered to be upregulated in growth arrested fibroblasts. $^{35,36}$ It should be noticed that PMP22 protein expression was shown to be elevated in the proliferative phase of human endometriosis. ${ }^{37}$ Moreover, PMP22 plays an important role in proliferation and invasion of some types of cancers such as osteosarcoma $^{38,39}$ and breast cancer. ${ }^{40}$

$P M P 22$ gene is under tight regulation and small changes in its expression can drastically influence myelination and, by extension, affect motor and sensory functions. ${ }^{41,42}$ Genetic abnormalities in PMP22 gene accounts for more than $50 \%$ of the inherited peripheral neuropathies including CMT1A, hereditary neuropathy with liability to pressure palsies (HNPP), Déjerine-Sottas syndrome and $\mathrm{CMT}^{4} \mathrm{E}^{43}$ (Fig 1). Overexpression of PMP22 levels resulting from the trisomy of PMP22 gene lead to CMT1A.

HNPP is an autosomal dominant inherited neuropathy that causes episodes of numbness and weakness. It is due to deletion of one copy of PMP22 gene on chromosome $17 \mathrm{p} 11.2$. Its symptom onset is at the second and third decade of life although some symptoms start at early age. Similar to CMT patients, HNPP may be asymptomatic and shows intrafamilial phenotypic variability. Electrophysiological studies demonstrated increased distal motor latencies and reduced motor and sensory NCV. The pathological characteristic of HNPP is the presence of. tomaculas, which are massive

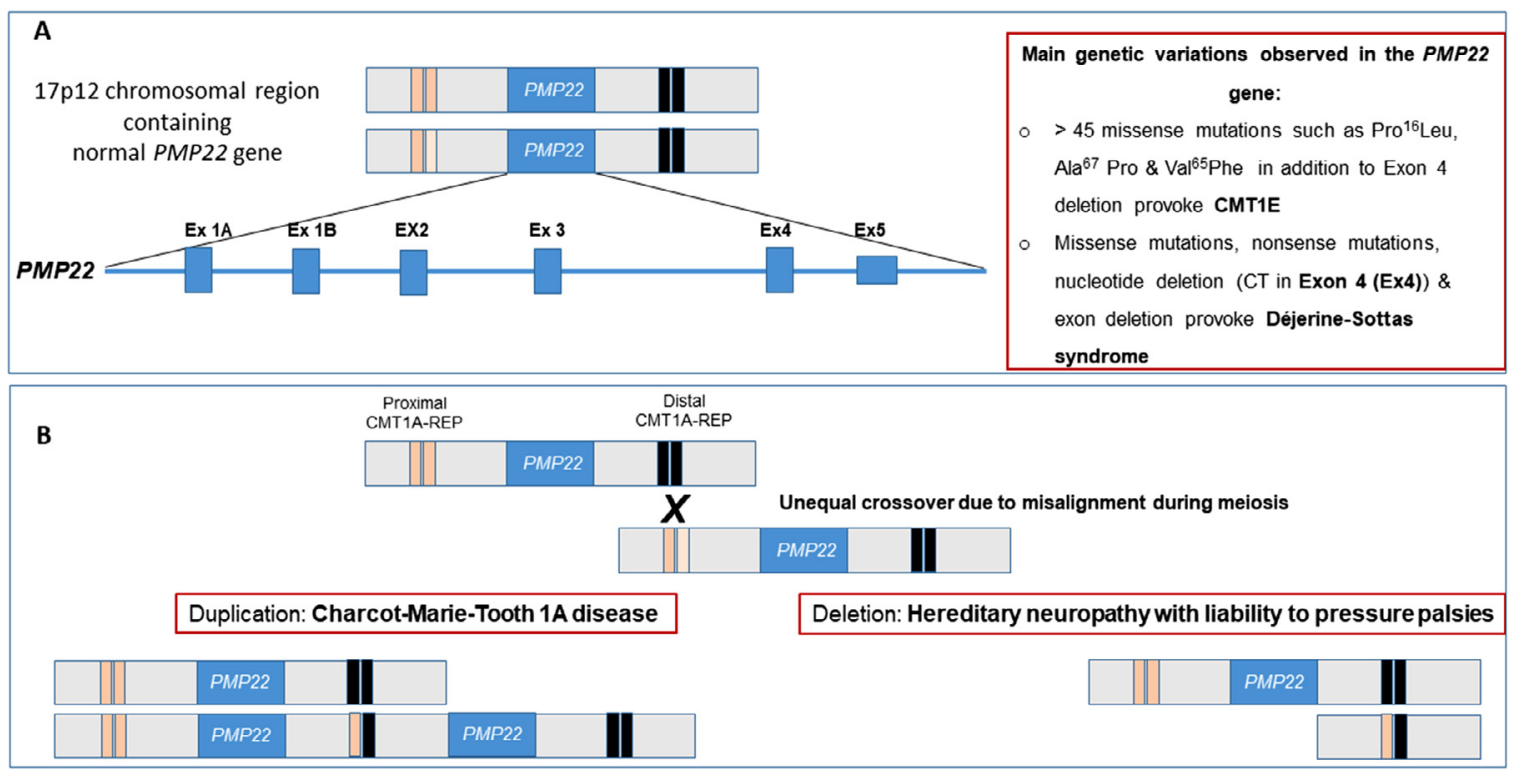

Fig. 1. Pathologies related to $P M P 22$ gene. A, Representation of chromosome $17 \mathrm{p} 11.2$ region; the normal $P M P 22$ gene that carry 5 exons (Ex) is highlighted in between two lines. The principal genetic variations described in the literature that lead to Charcot Marie Tooth 1E (CMT1E) and Dejerine-Sottas syndrome (DSS) are emphasized in the red box. B, Shows an unequal crossover in ch17p11.2 region due to misalignment during meiosis leading to either $1.5 \mathrm{Mb}$ duplication or deletion responsible for the CMT1A or Hereditary neuropathy with liability to pressure palsy (HNLP) diseases. Unequal crossover is mediated by CMT1A-REPs which are conserved $27 \mathrm{~kb}$ pair sequences flanking the $1.5 \mathrm{Mb}$ region of ch $17 \mathrm{p} 11.2$. 
folding of layers of variable thickness in the myelin sheath. ${ }^{44}$ That's why it is also known as tomacular neuropathy.

CMT1E is referred to the CMT1 subtype resulting from PMP22 gene point mutations. Mutations alters the protein amino acid sequence and can lead to gain of new function of the gene or loss of gene function due to premature termination of translation similar to HNPP pathology. ${ }^{45}$ One of the severe heterozygote point mutations on PMP22 gene mice is the Leu ${ }^{16}$ Pro. This point mutation is also expressed in the transgenic trembler J mouse model. It leads to abnormal Schwann cell-axon interaction, demyelination and axonal loss. The severity of the phenotype in the PMP22 point mutation is mainly due to loss of intact PMP22 at the plasma membrane and cellular stress induced by misfolded PMP22. ${ }^{46}$ Point mutations disrupt PMP22 plasma membrane trafficking resulting in its misfolding. Misfolded PMP22 is directly targeted by the endoplasmic reticulum (ER) associated degradation for clearance. However, the clearance by ER is not $100 \%$ efficient thus causing cellular aggregation of PMP22 resulting in cellular stress. ${ }^{47}$ Indeed, this excess in $P M P 22$ aggregates was detected in sural nerve biopsies of CMT1E patients harboring the PMP22 mutation but not in sural nerve biopsies of CMT1A patients. ${ }^{48}$ This highlights the difference between CMT1E and CMT1A neuropathies.

Dejerine-Sottas syndrome is an early onset demyelinating hereditary neuropathy that occurs in the first two years of life. It is characterized by a very low MNCV of less than $12 \mathrm{~m} / \mathrm{s}$, thin myelin sheath and onion bulb formation. It shows common symptom with CMT as muscle wasting, weakness and foot deformity. It is caused by $P M P 22$ or MPZ genes mutations. ${ }^{45}$

CMTIA: the most frequent CMT subtype. CMT1A represents $60 \%-70 \%$ of all CMT. ${ }^{49}$ It is caused by duplication of a 1.4 mega base $(\mathrm{Mb})$ region on chromosome 17 p11.2 that lead to overexpression of PMP22 gene g,49 $^{8}$ due to unequal crossover during meiosis. ${ }^{50}$ An increase of PMP22 levels has been reported in biopsies from sural nerve of CMT1A patients using immunological electron microscopy. ${ }^{51}$ However, using skin biopsy techniques it has been shown that the PMP22 mRNA expression and protein levels are variable in CMT1A patients. ${ }^{52}$ It has been speculated that the PMP22 levels fluctuate over time. ${ }^{53}$ At a certain time point, $P M P 22$ level will be either elevated or normal. ${ }^{54}$ This variability was also detected in a study to define Schwann cell biomarkers from skin biopsies using RNA-seq technique and a digital gene expression platform by nanostring technology. Using this approach, Svaren et al, were able to detect an increase in PMP22 expression by 1.5-2 folds in skin biopsies from CMT1A patients when normalized to Schwann cells specific genes. 55 This method can be helpful for CMT1A clinical trials to detect the changes of PMP22 and other CMT1A related genes such as L1 cell adhesion molecule $(L 1 C A M)$ and nerve growth factor receptor $(N G F R) .^{55}$

Moreover, to better understand CMT1A pathology and find new targeted therapy, several sensitive biomarkers reflecting CMT1A impairment and progression have been studied recently. These biomarker can be helpful in the diagnosis and the detection of the severity of CMT1A. Measurements of intramuscular fat fraction of calf muscle that was found to be increased in CMT1A patient could be one of them. ${ }^{56}$ Another biomarker found to be elevated in CMT1A plasma sample is the neurofilament $\mathrm{L}$ protein that was correlated with the increase in the severity of CMTN scores in CMT1A patient. ${ }^{57} \mathrm{~A}$ new specific biomarker for CMT1A was recently identified by Wang et al. ${ }^{58}$ The transmembrane protease serine 5 (TMPRSS5) protein was found to be elevated by around 2-folds in the plasma of CMT1A patients. ${ }^{58}$ Moreover, several genes were found to be alteredin PMP22 transgenic mouse model ( $\mathrm{TgN} 248)$ that could be targeted for future therapy. ${ }^{59}$

Since the discovery of the main cause of CMT1A, that is $P M P 22$ overexpression resulting from the trisomy of PMP22 gene in addition to neurological dysfunctions which are due to loss of large-caliber motor and sensory axons, several animal models and therapeutic strategies were developed.

Rat CMT1A model and TgN248, C22, C61 or C3 mouse models were generated by random insertion of a fragment of mouse or human PMP22 cDNA into their genome. These mice showed an increase of PMP22 level paralleled with slow conduction velocity and dysmyelination ${ }^{60-67}$ (Table II). However, some of these rodent models (TgN248 and C22) partially failed to mimic the human CMT1A as they showed very high levels of PMP22 in Schwann cell due to the high number of $P M P 22$ copies inserted in each strain. These models are quite severe from early onset and they don't recapitulate the histopathological and clinical phenotype of CMT1A disease. They are artificial disease-models that were used to understand the disease process for translation medicine. Indeed, the duplication in human CMT1A is 1,4 Mb DNA segment which make it hard to generate a humanized rodent model of CMT1A and the rodent model failed to reflect the altered genome structure and did not show the variability in the PMP22 level found in CMT1A patients. ${ }^{53}$ This may explain why several drug strategies failed to give positive results when transferred from rodent models to human CMT1A patients. 
Table II. CMT1A animal models. The most frequent animal models used to test drugs

\begin{tabular}{|c|c|c|c|c|}
\hline $\begin{array}{l}\text { CMTIA transgenic } \\
\text { animal models }\end{array}$ & $\begin{array}{l}\text { Origin of the PMP22 } \\
\text { insertion }\end{array}$ & $\begin{array}{l}\text { Number of PMP22 } \\
\text { extra copies }\end{array}$ & Phenotype & References \\
\hline C61 mouse & Human PMP22 YAC & 4 & $\begin{array}{l}\text { Mild demyelination } \\
\text { MNCV } 25 \mathrm{~m} / \mathrm{s}\end{array}$ & Huxley et al, $1998^{60}$ \\
\hline C3-PMP mouse & Human PMP22 YAC & 4 & $\begin{array}{l}\text { Mild neuromuscular } \\
\text { impairment }\end{array}$ & $\begin{array}{l}\text { Verhammeet al, } \\
2011^{66}\end{array}$ \\
\hline C22 mouse & Human PMP22YAC & 7 & Severe demyelination & Huxley et al, $1996^{60}$ \\
\hline TgN248 mouse & $\begin{array}{l}\text { Mouse Pmp22cosmid } \\
\text { PTCF-6. } 1\end{array}$ & 16 & $\begin{array}{l}\text { Very severe demye- } \\
\text { lination leading to } \\
\text { age-related } \\
\text { paralysis }\end{array}$ & Magyar et al, $1996^{61}$ \\
\hline $\begin{array}{l}\text { JP18/JY13 tetracy- } \\
\text { cline conditional } \\
\text { transgenic mouse }\end{array}$ & $\begin{array}{l}\text { Mouse Pmp22 plas- } \\
\text { mid pJP7m Human } \\
\text { PMP22YAC }\end{array}$ & 2 & $\begin{array}{l}\text { Moderate demyelin- } \\
\text { ation at } 16 \text { weeks of } \\
\text { age }\end{array}$ & $\begin{array}{l}\text { Pereaet al, } 2001^{65} \\
\text { Robertson et al, } \\
2002^{64}\end{array}$ \\
\hline PMP22 transgenic rat & Mouse Pmp22cosmid & 3 & Mild demyelination & $\begin{array}{l}\text { Seredaet al, } 1996^{62} \\
\text { Fledrichet al, } 2012^{67}\end{array}$ \\
\hline
\end{tabular}

Interestingly, the tetracycline conditional model has not been used until now for treatment testing. ${ }^{65}$ This transgenic model was made to overexpress PMP22 under specific control where in the absence of tetracycline since birth, the PMP22 gene is overexpressed, thus leading to dysmyelination in the embryonic life followed by demyelination in about $26 \%$ of myelinated nerve fibers in adult mice. ${ }^{64}$ These observations are in parallel with the finding in human CMT1A patient. Dysmyelination was detected in young patients with CMT1A without affecting the $\mathrm{NCV}^{68}$ whereas, demyelination was detected in adults CMT1A patients. ${ }^{69}$ Normalization of PMP22 expression by tetracycline administration led to a rapid remyelination. ${ }^{65}$ Therefore, this model could be useful to introduce a personalized medicine based on normalization of PMP22 expression to reverse the CMT1A neuropathy.

Until now, there is no effective CMT1A treatment despite worldwide efforts of several research groups and the existence of representative animal models of this disease ${ }^{60-67}$ (Table II). At this time, physical therapy and surgical corrections are the only available treatments. $^{12,70,71}$

At the beginning of the 21 st century, efforts were made to modulate the activity of signaling proteins acting upstream of the PMP22 gene such as adenylatecyclase using ascorbic acid or the progesterone receptors using the selective antagonist onapristone. Nowadays, molecules acting on adenylatecyclase activity, tyrosine kinase receptor or on pain are tested to reduce the progression of CMT1A.

The future treatment options for CMT1A may involve specific targeting of the PMP22 gene. All the mentioned molecules and their clinical outcomes are further discussed. Table III and Fig 2 summarize the past, recent, and future treatments as well as the signaling pathwaystargeting $P M P 22$ expression.

Ascorbic acid and onapristone. Adenylatecyclase use ATP as a substrate to increase the intracellular levels of cyclic adenosine monophosphate (cAMP). The first compound tested targeting cAMP was ascorbic acid also known as Vitamin C. ${ }^{72,73}$ In fact, ascorbic acid acts as a competitive inhibitor of adenylatecyclase activity and thus decrease the intracellular levels of cAMP. ${ }^{74}$ Ascorbic acid is a water-soluble compound composed of 6 carbons with 2 ionizable hydroxyl groups. It is an essential nutrient in the human diet that is required for the synthesis of collagen in fibrous tissues, bones, teeth, capillaries, and skin. It is a reducing agent and a powerful antioxidant. It gained interest for its two roles as a neuroprotector and neuromodulator. ${ }^{75}$ Noteworthy, it was tested as a treatment of CMT1A because (1) it is easily synthesized and commercially available, (2) vitamin C deficiency leads to PNS dysfunction and, (3) it promotes myelination of Schwann cells in vitro. ${ }^{76}$

Passage et al, $^{76}$ have shown that weekly treatment, with $1.2 \mathrm{mg}$ of ascorbic acid for a $20 \mathrm{~g} \mathrm{CMT1A}$ mice (C22) carrying 7 extra copies of human PMP22 gene, improved locomotion, myelination and the life span and decreased PMP22 mRNA levels in sciatic nerves. ${ }^{60}$ Based on this study, several clinical trials have been performed. A study conducted by Shy et al on CMT1A patients showed that daily administration of $1 \mathrm{~g}$ of ascorbic acid for one year had no significant effect on the motor and sensory activities. ${ }^{77}$ Micallef et al observed the same results even after increasing the dose to $3 \mathrm{~g} .{ }^{78}$ The same year, another clinical trial was conducted on young CMT1A patients' age below 25 years, and no significant improvement in myelination was recorded. In this study myelination was 
Table 3. Main drugs tested for CMT1A disease. The targeted receptors, animal models used, administration route and type of research done are shown

\begin{tabular}{|c|c|c|c|c|c|}
\hline $\begin{array}{l}\text { Drug } \\
\text { nomenclature }\end{array}$ & $\begin{array}{l}\text { Receptor or } \\
\text { transporter and } \\
\text { pathway }\end{array}$ & Animal models & $\begin{array}{l}\text { Number of } P M P 22 \\
\text { gene copies and } \\
\text { age at start of } \\
\text { treatment }\end{array}$ & $\begin{array}{l}\text { Administration } \\
\text { route \& treatment } \\
\text { duration }\end{array}$ & Investigation type \\
\hline Onapristone & $\begin{array}{c}\text { Progesterone } \\
\text { receptor } 1 \\
\text { antagonist }\end{array}$ & CMTlA Rat & 3 Copies P5 & $\begin{array}{l}\text { Subcutaneous Six } \\
\text { weeks }\end{array}$ & Research \\
\hline Ascorbic acid & $\begin{array}{l}\text { Sodium-Depen- } \\
\text { dent Vitamin C } \\
\text { Transporter } 2 . \\
\text { Reduce Adyne- } \\
\text { lateCyclase } \\
\text { Activity cAMP } \\
\text { pathway }\end{array}$ & C22 mice & 7 Copies P5 & $\begin{array}{l}\text { Force feeding } \\
\text { Once per week } \\
\text { till death }\end{array}$ & $\begin{array}{l}\text { Research, Preclini- } \\
\text { cal and Clinical } \\
\text { studies }\end{array}$ \\
\hline $\begin{array}{l}\text { Neurotrophin-3 } \\
\text { SCAAV1.tMCK. } \\
\text { NTF3 }\end{array}$ & $\begin{array}{l}\text { Nerve growth fac- } \\
\text { tor, tyrosine } \\
\text { Kinase receptor }\end{array}$ & $\begin{array}{c}\text { Trembler J mice \& } \\
\text { xenografts from } \\
\text { CMT1Apatients }\end{array}$ & $\begin{array}{l}\text { Point mutation 6-8 } \\
\text { weeks }\end{array}$ & $\begin{array}{l}\text { Intramuscular } 20 \\
\text { and } 40 \text { weeks }\end{array}$ & $\begin{array}{l}\text { Research, preclini- } \\
\text { cal and clinical } \\
\text { study recruiting }\end{array}$ \\
\hline РХT3003 & $\begin{array}{l}\text { i) } \mathrm{GABA}_{\mathrm{B}} \text { receptor } \\
\text { agonist, ii) nar- } \\
\text { cotic antagonist } \\
\text { and iii) musca- } \\
\text { rinic receptor } \\
\text { antagonist }\end{array}$ & CMT1A Rat & 3 copies 4 weeks & $\begin{array}{l}\text { Oral gavage daily } \\
\text { For } 4 \text { months }\end{array}$ & $\begin{array}{l}\text { Research, Preclini- } \\
\text { cal and Clinical } \\
\text { (Phase II and } \\
\text { Phase III ongoing } \\
\text { trials) }\end{array}$ \\
\hline siRNALeu ${ }^{16}$ Pro & $\begin{array}{l}\text { Leu }^{16} \text { PMP22 point } \\
\text { mutation siRNA } \\
\text { machinery }\end{array}$ & Trembler J mice & $\begin{array}{l}\text { Point mutation P5 } \\
\text { or P6 }\end{array}$ & $\begin{array}{l}\text { Intraperitoneal } 2 \\
\text { weeks }\end{array}$ & Research \\
\hline $\begin{array}{l}\text { ASO directed } \\
\text { against PMP22 }\end{array}$ & $\begin{array}{l}\text { PMP22 mRNA } \\
\text { expression Wat- } \\
\text { son-Crick Base } \\
\text { pairing }\end{array}$ & $\begin{array}{l}\text { C22 mice CMT1A } \\
\text { Rat }\end{array}$ & $\begin{array}{l}7 \text { copies/ } 5 \text { weeks } \\
3 \text { copies/ } 6 \\
\text { weeks }\end{array}$ & $\begin{array}{l}\text { Subcutaneous } 9 \\
\text { weeks for C22 } 12 \\
\text { weeks for rats }\end{array}$ & Research \\
\hline
\end{tabular}

assessed by measuring the MNCV as a primary outcome while the secondary outcomes were CMAP, muscle strength, sensory functions and Charcot Marie tooth neuropathy score (CMTNS). ${ }^{79}$ To assess the efficacy and safety of ascorbic acid in CMT1A patients a multicenter 2-year study was conducted in United Kingdom and Italy, and found that ascorbic acid treatment had no significant adverse events but also no effect on CMTNS. $^{80}$

It is well-known that ascorbic acid is up taken by Schwann cells through the sodium-dependent vitamin $\mathrm{C}$ transporter $2,{ }^{81,82}$ and acts as a competitive inhibitor of adenylate cyclase. ${ }^{83}$ Knowing that cAMP is a crosslink for different signaling pathways, the effect of ascorbic acid on PMP22 gene expression could be reduced. In addition, the use of a severe demyelinating mouse model (C22) that may not reflect the CMT1A neuropathy could explain the absence of response to Vitamin C in CMT1A patients.

In the same period, Sereda et al, speculated that inhibiting the action of progesterone at its receptor may be a treatment for CMT1A. ${ }^{84}$ Progesterone stimulates promoter 1 of $P M P 22$ gene through the progesterone receptor which is expressed in Schwanncells. ${ }^{85,86}$ Onapristone, a progesterone receptor antagonist, is known to prevent progesterone receptor dimerization which is required for its transcriptional activity. ${ }^{87,88}$ Administration of onapristone improved CMT1A phenotype and decreased PMP22 mRNA expression in rats. ${ }^{84}$ Subsequently, a long-term study of 5 months duration was conducted on PMP22 overexpressing rats and confirmed the beneficial effects of onapristone. ${ }^{84,89}$ However, in clinical trials, liver toxicity was found to be a major limitation for the use of onapristone (NCT02600286). ${ }^{8,90}$

Drugs in development for the treatment of CMTIA. Neurotrophin-3 (NT-3) plays an important role in the development, functioning and plasticity of the nervous system. ${ }^{91-93}$ It binds to 3 Tyrosine kinase receptors (TrK) with a great affinity for TrkC. ${ }^{94}$ NT3 has been studied for development of treatment for CMT pathology in both the trembler-J mice which have a demyelinating phenotype and xenograft of CMT1A patients. In 2005, NT-3 treatment was shown to improve axonal regeneration and to significantly increase the number of solitary myelin fiber as well as their diameter in 


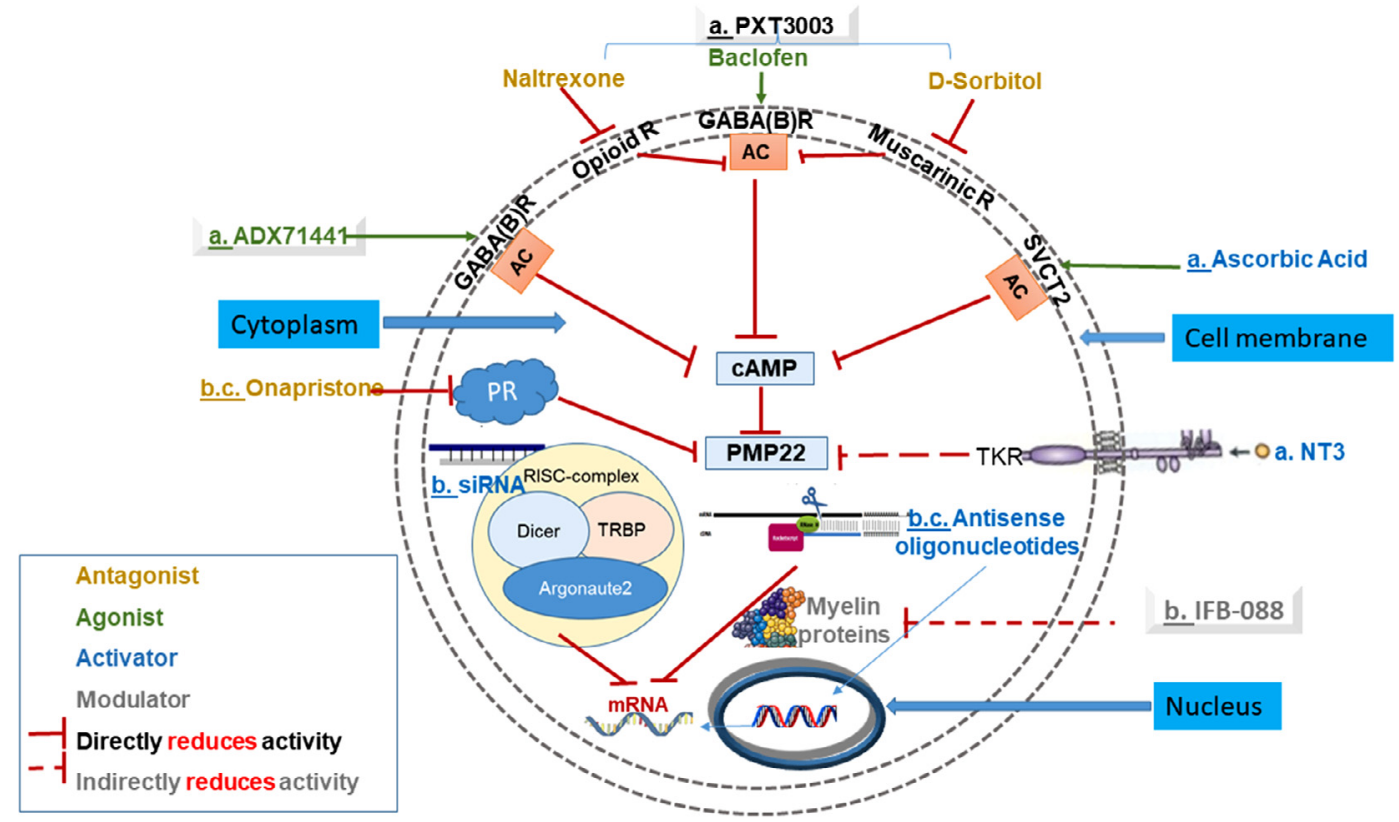

Fig. 2. Drugs and Pathways. Representative diagram showing some of the drugs tested for CMT1A treatments and the pathways involved. a, Several membrane receptors were targeted by one molecule (ascorbic acid, ADX71441, NT3) or a combination of 3 molecules (PXT3003) to inhibit PMP22 expression directly or indirectly through regulation of adenylatecyclase (AC) activity (cAMP) or tyrosine kinase receptor (TKR). b, progesterone receptor (PR) antagonist (onapristone) and nucleic acids such as siRNA and antisense oligonucleotides (ASO) are used to inhibit directly the $P M P 22$ expression or to indirectly modulate its expression through molecules acting on myelin proteins (IFB-088). c, PR and ASO can have a double localization cytoplasmic and nuclear.

Trembler-J mice and in animal models having xenografts from CMT1A patients. ${ }^{95,96}$ However,the short plasmatic half-life of NT-3 hurdled its use as an effective long-term treatment for CMT1A patients. Thus, NT-3-encoding AAV1 vectors were delivered intramuscularly to Trembler-J mice carrying Leu ${ }^{16}$ Pro point mutation in the putative first transmembrane region of the $P M P 22$ polypeptide. ${ }^{97}$ In Trembler-J mice, AAV1NT-3 increased the serum levels of NT3, improved the sensory and motor functions ${ }^{95}$ and promoted axonal regeneration after peripheral nerve injury. ${ }^{98,99}$ Recently, a "CMT Gene Therapy Program" was launched with hope to use of AAV1-NT3 for future CMT1A clinical trials (NCT03520751).

Chumakov et al, combined 3 commercially available drugs targeting several pathways involved in myelination and acting together to increase directly or indirectly the intracellular levels of cAMP. ${ }^{100}$ This combination therapy named PXT3003 comprises: (1) (RS)-baclofen, a selective $\mathrm{GABA}_{\mathrm{B}}$ receptor agonist and a skeletal muscle relaxant, (2) naltrexone, a noroxymorphone derivative with competitive opioid and narcotic antagonistic activities, and (3) D-sorbitol, a muscarinic receptor antagonist and laxative. It was tested on the CMT1A transgenic rat model carrying three extra copies of mouse PMP22 gene with 1.6-fold increase in PMP22 expression. ${ }^{49,100}$ In rats, PXT3003 treatment down-regulated $P M P 22$ gene expression and improved nerve conduction velocity and CMT1A clinical phenotype ${ }^{100}$ Moreover, in newborn CMT1A rats, PXT3003 decreased PMP22 mRNA expression and ameliorated the motor activity. Furthermore, it regulated the misbalanced downstream the PI3K-AKT/ MEK-ERK signaling pathway. ${ }^{101}$

A Phase II clinical study of PXT3003 conducted in randomized, double-blind and placebo-controlled groups of CMT1A patients confirmed its safety and tolerability. However, an efficacy of the treatment was only observed in the high-dose group, with significant improvement in the Overall Neuropathy Limitation Scale. ${ }^{102}$ To compare the clinical outcomes of PXT3003 and ascorbic acid that both target cAMP, a meta-analysis of randomized double-blind clinical trials was conducted. PXT3003 showed enhancement of CMTNS and Overall Neuropathy Limitation Scale in comparison with ascorbic acid patients, who were stable but not significantly different from the placebo group. ${ }^{103}$ This encouraged pursuing, and a phase III PXT3003 clinical trial (NCT02579759) is ongoing. In 
case of success, this treatment could open a therapeutic approach for CMT1A patients.

IFB-088 or sephin 1 is a new molecule, designated as an orphan drug by the US Food and Drug Administration (FDA) and European Medicines Agency (EMA). Sephin 1 is involved in controlling the misfolding of myelin proteins that occurs during mechanical, thermal and oxidative stress. ${ }^{104}$ The development of this drug candidate (preclinical and Phase I trial) is supported by AFM-Telethon (NCT03610334). Preclinical studies have shown that the administration of sephin1 in mouse models of CMT1A or CMT1B, which is cause by mutation in $M P Z$, restores motor functions. ${ }^{105}$ In May 2018, approval to start a Phase I trial of IFB-088 in 72 healthy volunteers was announced. If the results are positive, a Phase II trial will be conducted in patients with CMT1A or CMT1B.

ADX71441 and FLX-787 are pain-modulating drugs. ADX71441 is a modulator of GABAB receptor. ${ }^{106}$ It was tested in rodent models and showed efficiency for the treatment of anxiety, pain and spasticity. Activating GABAB receptor reduces $P M P 22$ gene expression. $^{107}$ ADX71441 has received regulatory approval to start a Phase 1 trial (not listed in the Clinical Trials website) and is being investigated for its therapeutic use in CMT1A. FLX-787 is a small molecule that acts as antispastic and muscle relaxant and was tested on CMT1A patients. Phase II COMMIT trial (NCT03254199) was stopped due to low tolerance.

What is the future of CMTlA treatment? Oligonucleotides: a golden opportunity for CMTIA treatment. Small interfering RNA (siRNA) was recently recognized as an extraordinary breakthrough reflected by the increase in clinical studies over the last few years. In the PNS, the success story using siRNA for treatment of Hereditary Transthyretin Amyloidosis (hATTR), a lethal disease caused by tranthyretin (TTR) systemic accumulation, gave a boost to siRNA research in the PNS disorders field. Preclinical data showed that inhibition of hepatic TTR gene by siRNA reduced systematic levels of TTR, thus stabilizing TTR deposits in several tissues. ${ }^{108}$ Then, clinical phases were conducted, the latest is the Apollo phase III clinical study, where Patisiran, the siRNA against TTR was shown to improve clinical disease manifestations. ${ }^{109,110}$ Patisiran received approval from the FDA and EMA and is now used in clinical practice. This raises hope for other siRNAs to reach clinical trials.

For CMT1 neuropathy, Lee et al, designed 19 siRNAs specific for the mutation Leu ${ }^{16}$ Pro responsible for the development of CMT1E. ${ }^{111}$ First, they tested their efficiency on cultured Schwann cells, and then identified one siRNA able to counteract the effects of the Leu ${ }^{16}$ Pro mutation. After that, the siRNA Leu ${ }^{16}$ Pro was administered to Trembler-J mice by a nonviral delivery system via intraperitoneal injection at the postnatal age of 6 days. Interestingly, improvement in motor function and muscle volume, paralleled with an increase in motor nerve conduction velocity and CMAP, was observed. In addition, myelination was increased in the sciatic nerve with a simultaneous increase in the expression of the myelin genes Myelin Basic Protein (MBP) and Myelin Protein Zero (MPZ). They concluded that suppression of the PMP22 mutant allele by nonviral delivery of siRNA could restitute CMT1 neuropathic phenotype. ${ }^{111}$ This was a proof of concept study showing that siRNA could reach the peripheral nervous system and suggest that siRNA administration at postnatal day 6 may raise questions toward clinical translation of CMT disorders with primary Schwann cell genetic defects.

Another oligonucleotide approach is to inhibit gene expression using synthetic antisense oligonucleotides (ASO). ASO are 12-30 base pairs in length that use the RNAse H1 nuclease to induce RNA degradation. ${ }^{112,113}$ In 2018, ASO TTR (inotersen) obtained marketing authorization for hATTR by FDA and EMA and is now also used in clinical practice. ${ }^{114}$

Concerning CMT1A, Zhao et al designed two ASOs against PMP22 gene expression, both of them improving severe and moderate forms of rodent CMT1A models but at high dose level $(100 \mathrm{mg} / \mathrm{kg}) .{ }^{115}$ The use of high-dose of ASO or siRNA could dysregulate other genes, named the "off-target effect" and impedes their use as a treatment. Knowing that CMT1A is a genetic disease requiring a lifelong treatment, the dose of ASO and siRNA should be carefully designed to prevent toxic adverse events (thrombocytopenia, nephrotoxicity, hepatotoxicity, proinflammatory effects). ${ }^{116}$

It should also be noted that both SiRNA and ASO are unstable in vivo and require modifications to be effective. Nanotechnology development allows to overcome this barrier and to carry siRNA to their targets. This is attested by the recent success of Patisiran, based on a lipid nanoparticle (LNP) system for vectorizing siRNA. ${ }^{117}$ For ASO, phosphothioate modification is the first and most common modification used to date. ASO bearing phosphothioate-modified DNA and 2'sugar modifications are water soluble, and show increased stability and uptake by cells. ${ }^{115,118}$

Although studies by Lee et $a l^{111}$ using siRNA and Zhao et $a l^{115}$ using ASO against PMP22 gave hope to patients with CMT1A, further investigation is required to define the optimal conditions and sequence of siRNA and ASO. Safety and pharmacokinetics studies must be completed to insure the tolerability of the siRNA and to achieve tight regulation of PMP22 gene expression, as its inhibition below normal levels can 
lead to HNPP. ${ }^{119}$ Overall, the RNAi approach should be investigated since it opens a new hope for CMT1A disease as well as for other hereditary neuropathies.

Targeting macrophages and heat shock proteins may help preventing CMTIA progression. CMT1A is characterized by an increase in PNS macrophages and accumulation of PMP22 aggregates in Schwann cells. ${ }^{120}$ Therefore, targeting monocyte chemoattractant protein-1 (MCP-1/CCL2) and enhancement of Heat Shock Proteins (HSPs) would represent new therapeutic approaches for CMT1A. To this end, Kohl et al, showed that reduced levels of MCP-1/CCL2 are paralleled by a reduction in the number of macrophages in the CMT1A mouse strain C61 carrying four extra copies of human PMP22. ${ }^{60,121}$ To counteract the buildup of misfolded Pmp22, ChittoorVinod et al, enhanced the HSP70 expression and improved proteasome activity thus preventing aggregation of PMP22. ${ }^{122}$ It should be noticed that ethoxyquin, an antioxidant used to protect against neurotoxicity of chemotherapeutic agents and known to be a modulator of HSP90 ${ }^{123}$ could become effective as a treatment for CMT1A patients. ${ }^{124}$

\section{CONCLUSION}

Since the discovery of CMT1A in the 19th century, several drugs have been tested. However, most of them did not provide significant clinical benefits. Today, CMT is considered an economic burden with an annual cost of around $10,000 €$ per patient. ${ }^{125}$

The untreated CMT1A disease may become "treatable" in the next few years. The polytherapeutic approach PXT3003 is still evaluated, with the design of a new phase III clinical study. Another approach, which is making its way toward clinical trials, is the use of the RNAi machinery. Until now, most of the studies focused on reducing cAMP activity upstream of PMP22 instead of targeting directly PMP22 gene expression. Regulation of PMP22 gene expression using siRNA can be beneficial once proven safe and tolerable in CMT1A patients. This genetic approach paves the way for treatment of other inherited neuropathies.

\section{ACKNOWLEDGMENTS}

This work is supported by a public grant overseen by the French National Research Agency (ANR) as part of the "Investissementsd'Avenir" program (LabexNanoSaclay, reference: ANR-10-LABX-0035). The funding source was not involved in the collection, and interpretation of data. All authors have read the journal's authorship agreement and declare that they do not have conflict of interest.

\section{REFERENCES}

1. Remiche G, Kadhim H, Maris C, Mavroudakis N. [Peripheral neuropathies, from diagnosis to treatment, review of the literature and lessons from the local experience]. Revue Med Bruxelles 2013;34:211-20.

2. Bhatheja K, Field J. Schwann cells: origins and role in axonal maintenance and regeneration. Int $\mathrm{J}$ Biochem Cell Biol 2006;38:1995-9.

3. Kidd GJ, Ohno N, Trapp BD. Biology of Schwann cells. Handb Clin Neurol 2013;115:55-79.

4. Jessen KR, Mirsky R. The repair Schwann cell and its function in regenerating nerves. J Physiol 2016;594:3521-31.

5. Esposito S, Longo MR. Guillain-Barré syndrome. Autoimmun Rev 2017;16:96-101.

6. Dyck PJB, Tracy JA. History, diagnosis, and management of chronic inflammatory demyelinating polyradiculoneuropathy. Mayo Clin Proc 2018;93:777-93.

7. Shibuya K, Tsuneyama A, Misawa S, et al. Different distribution of demyelination in chronic inflammatory demyelinating polyneuropathy subtypes. J Neuroimmunol 2020;341:577170.

8. Jerath NU, Shy ME. Hereditary motor and sensory neuropathies: Understanding molecular pathogenesis could lead to future treatment strategies. Biochim Biophys Acta 2015;1852:667-78.

9. Timmerman V, Strickland AV, Zuchner S. Genetics of Charcot-Marie-Tooth (CMT) disease within the frame of the human genome project success. Genes (Basel) 2014;5:13-32.

10. Morena J, Gupta A, Hoyle JC. Charcot-Marie-Tooth: from molecules to therapy. Int J Mol Sci 2019;20:3419.

11. Laura M, Pipis M, Rossor AM, Reilly MM. Charcot-MarieTooth disease and related disorders: an evolving landscape. Curr Opin Neurol 2019;32:641-50.

12. Corrado B, Ciardi G, Bargigli C. Rehabilitation Management of the Charcot-Marie-Tooth syndrome: a systematic review of the literature. Medicine 2016;95:e3278.

13. Pipis M, Rossor AM, Laura M, Reilly MM. Next-generation sequencing in Charcot-Marie-Tooth disease: opportunities and challenges. Nat Rev Neurol 2019;15:644-56.

14. Ramchandren S. Charcot-Marie-Tooth Disease and other genetic polyneuropathies. Continuum (MinneapMinn) 2017;23:1360-77.

15. Drew AP, Zhu D, Kidambi A, et al. Improved inherited peripheral neuropathy genetic diagnosis by whole-exome sequencing. Mol Genet Genomic Med 2015;3:143-54.

16. Perveen S, Mannan S, Hussain A, Kanwal S. Charcot-MarieTooth type $1 \mathrm{~A}$ disease from patient to laboratory. JPMA J Pak Med Assoc 2015;65:206-12.

17. Kotruchow K, Kabzinska D, Karpinska K, Kochanski A. [Molecular pathogenesis of hereditary motor and sensory neuropathy]. Postepy Biochem 2011;57:283-93.

18. Pareyson D, Marchesi C, Salsano E. Hereditary predominantly motor neuropathies. Curr Opin Neurol 2009;22:451-9.

19. Kleopa KA, Scherer SS. Molecular genetics of X-linked Charcot-Marie-Tooth disease. Neuro Mol Med 2006;8:107-22.

20. Echaniz-Laguna A. The shifting paradigm of Charcot-MarieTooth disease. Rev Neurol (Paris) 2015;171:498-504.

21. Nam SH, Kanwal S, Nam DE, et al. Association of miR149 polymorphism with onset age and severity in CharcotMarie-Tooth disease type 1A. Neuromusc Disord 2018;28:502-7.

22. Bouhy D, Timmerman V. [Animal models of Charcot-MarieTooth disease and their relevance for understanding the disease in humans]. Revue Neurol 2013;169:971-7. 
23. Bouhy D, Timmerman V. Animal models and therapeutic prospects for Charcot-Marie-Tooth disease. Ann Neurol 2013;74:391-6.

24. Colomer J, Gooding R, Angelicheva D, et al. Clinical spectrum of CMT4C disease in patients homozygous for the p.Arg1109X mutation in SH3TC2. Neuromusc Disord 2006;16:449-53.

25. Snipes GJ, Suter U, Welcher AA, Shooter EM. Characterization of a novel peripheral nervous system myelin protein (PMP-22/SR13). J Cell Biol 1992;117:225-38.

26. Lee S, Bazick H, Chittoor-Vinod V, Al Salihi MO, Xia G, Notterpek L. Elevated peripheral myelin protein 22, reduced mitotic potential, and proteasome impairment in dermal fibroblasts from Charcot-Marie-Tooth disease type 1a patients. Am J Pathol 2018;188:728-38.

27. Manfioletti G, Ruaro ME, Del Sal G, Philipson L, Schneider C. A growth arrest-specific (gas) gene codes for a membrane protein. Mol Cell Biol 1990;10:2924-30.

28. Patel CV, Gorski DH, LePage DF, Lincecum J, Walsh K. Molecular cloning of a homeobox transcription factor from adult aortic smooth muscle. J Biol Chem 1992;267: 26085-90.

29. Chanson JB, Echaniz-Laguna A, Blanc F, et al. Central nervous system abnormalities in patients with PMP22 gene mutations: a prospective study. J Neurol Neurosurg Psychiatry 2013;84:392-7.

30. Suter U, Snipes GJ, Schoener-Scott R, et al. Regulation of tissue-specific expression of alternative peripheral myelin protein-22 (PMP22) gene transcripts by two promoters. J Biol Chem 1994;269:25795-808.

31. Hai M, Bidichandani SI, Patel PI. Identification of a positive regulatory element in the myelin-specific promoter of the PMP22 gene. J Neurosci Res 2001;65:508-19.

32. Taylor V, Zgraggen C, Naef R, Suter U. Membrane topology of peripheral myelin protein 22. J Neurosci Res 2000;62:15-27.

33. Mittendorf KF, Marinko JT, Hampton CM, et al. Peripheral myelin protein 22 alters membrane architecture. Sci Adv 2017;3:e1700220.

34. Zhou Y, Miles JR, Tavori H, et al. PMP22 regulates cholesterol trafficking and ABCA1-mediated cholesterol efflux. J Neurosci 2019;39:5404-18.

35. Brancolini C, Marzinotto S, Edomi P. Rho-dependent regulation of cell spreading by the tetraspan membrane protein Gas3/ PMP22. Mol Biol Cell 1999; 10:2441-59.

36. Zoidl G, Blass-Kampmann S, D'Urso D, Schmalenbach C, Muller HW. Retroviral-mediated gene transfer of the peripheral myelin protein PMP22 in Schwann cells: modulation of cell growth. EMBO J 1995;14:1122-8.

37. Rao RG, Sudhakar D, Hogue CP, et al. Peripheral myelin protein-22 (PMP22) modulates alpha 6 integrin expression in the human endometrium. Reprod Biol Endocrinol 2011;9:56.

38. Liu S, Chen Z. The functional role of PMP22 gene in the proliferation and invasion of osteosarcoma. Med Sci Monit $2015 ; 21: 1976-82$.

39. Li X, Jiang H, Xiao L, Wang S, Zheng J. miR-200bc/429 inhibits osteosarcoma cell proliferation and invasion by targeting PMP22. Med Sci Monit 2017;23:1001-8.

40. Winslow S, Leandersson K, Larsson C. Regulation of PMP22 mRNA by G3BP1 affects cell proliferation in breast cancer cells. Mol Cancer 2013;12:156.

41. Garbay B, Heape AM, Sargueil F, Cassagne C. Myelin synthesis in the peripheral nervous system. Prog Neurobiol 2000;61:267-304

42. Monje M. Myelin plasticity and nervous system function. Annu Rev Neurosci 2018;41:61-76.
43. Suter U, Snipes GJ. Peripheral myelin protein 22: facts and hypotheses. J Neurosci Res 1995;40:145-51.

44. van Paassen BW, van der Kooi AJ, van Spaendonck-Zwarts KY, Verhamme C, Baas F, de Visser M. PMP22 related neuropathies: Charcot-Marie-Tooth disease type $1 \mathrm{~A}$ and Hereditary Neuropathy with liability to Pressure Palsies. Orph J Rare Dis 2014;9:38

45. Li J, Parker B, Martyn C, Natarajan C, Guo J. The PMP22 gene and its related diseases. Mol Neurobiol 2013;47:673-98.

46. Schlebach JP, Narayan M, Alford C, et al. Conformational stability and pathogenic misfolding of the integral membrane protein PMP22. J Am Chem Soc 2015;137:8758-68.

47. Tobler AR, Liu N, Mueller L, Shooter EM. Differential aggregation of the Trembler and Trembler $\mathrm{J}$ mutants of peripheral myelin protein 22. Proc Natl Acad Sci U S A 2002;99:483-8.

48. Hanemann CO, D'Urso D, Gabreels-Festen AA, Muller HW Mutation-dependent alteration in cellular distribution of peripheral myelin protein 22 in nerve biopsies from Charcot-MarieTooth type 1A. Brain 2000;123(Pt 5):1001-6.

49. Sereda MW, Nave K-A. Animal models of Charcot-MarieTooth disease type 1A. NeuroMol Med 2006;8:205-15.

50. Lee JH, Choi BO. Charcot-marie-tooth disease: seventeen causative genes. J Clin Neurol (Seoul, Korea) 2006;2:92-106.

51. Vallat JM, Sindou P, Preux PM, Tabaraud F, Milor AM, Couratier $\mathrm{P}$, et al. Ultrastructural $\mathrm{PMP} 22$ expression in inherited demyelinating neuropathies. Ann Neurol 1996;39:813-7.

52. Nobbio L, Visigalli D, Radice D, et al. PMP22 messenger RNA levels in skin biopsies: testing the effectiveness of a CharcotMarie-Tooth 1A biomarker. Brain 2014;137:1614-20.

53. Katona I, Wu X, Feely SM, et al. PMP22 expression in dermal nerve myelin from patients with CMT1A. Brain 2009;132:1734-40.

54. Li J. Caveats in the Established Understanding of CMT1A. Ann Clin Transl Neurol 2017;4:601-7.

55. Svaren J, Moran JJ, Wu X, et al. Schwann cell transcript biomarkers for hereditary neuropathy skin biopsies. Ann Neurol 2019;85:887-98.

56. Morrow JM, Evans MRB, Grider T, et al. Validation of MRC Centre MRI calf muscle fat fraction protocol as an outcome measure in CMT1A. Neurology 2018;91:e1125-e9.

57. Sandelius A, Zetterberg H, Blennow K, et al. Plasma neurofilament light chain concentration in the inherited peripheral neuropathies. Neurology 2018;90:e518-e24.

58. Wang H, Davison M, Wang K, et al. Transmembrane protease serine 5: a novel Schwann cell plasma marker for CMT1A Ann Clin Trans1 Neurol 2020;7:69-82.

59. Nattkamper H, Halfter $H$, Khazaei MR, et al. Varying survival of motoneurons and activation of distinct molecular mechanism in response to altered peripheral myelin protein 22 gene dosage. J Neurochem 2009;110:935-46.

60. Huxley C, Passage E, Manson A, et al. Construction of a mouse model of Charcot-Marie-Tooth disease type 1A by pronuclear injection of human YAC DNA. Hum Mol Genet 1996;5:563-9.

61. Magyar JP, Martini R, Ruelicke T, et al. Impaired differentiation of Schwann cells in transgenic mice with increased PMP22 gene dosage. J Neurosci 1996;16:5351-60.

62. Sereda M, Griffiths I, Puhlhofer A, et al. A transgenic rat model of Charcot-Marie-Tooth disease. Neuron 1996;16:1049-60.

63. Huxley C, Passage E, Robertson AM, et al. Correlation between varying levels of PMP22 expression and the degree of demyelination and reduction in nerve conduction velocity in transgenic mice. Hum Mol Genet 1998;7:449-58.

64. Robertson A, Perea J, Tolmachova T, Thomas PK, Huxley C. Effects of mouse strain, position of integration and tetracycline 
analogue on the tetracycline conditional system in transgenic mice. Gene 2002;282:65-74.

65. Perea J, Robertson A, Tolmachova T, et al. Induced myelination and demyelination in a conditional mouse model of Charcot-Marie-Tooth disease type 1A. Hum Mol Genet 2001;10:1007-18

66. Verhamme C, King RH, ten Asbroek AL, et al. Myelin and axon pathology in a long-term study of PMP22-overexpressing mice. J Neuropathol Exp Neurol 2011;70:386-98.

67. Fledrich R, Stassart RM, Sereda MW. Murine therapeutic models for Charcot-Marie-Tooth (CMT) disease. Br Med Bull 2012;102:89-113

68. Gabreels-Festen A, R VDW. Human nerve pathology caused by different mutational mechanisms of the PMP22 gene. Ann New York Acad Sci 1999;883:336-43.

69. Saporta MA, Katona I, Lewis RA, Masse S, Shy ME, Li J Shortened internodal length of dermal myelinated nerve fibres in Charcot-Marie-Tooth disease type 1A. Brain 2009; 132:3263-73.

70. Watanabe K. [Treatment for patients with Charcot-MarieTooth disease: orthopaedic aspects]. Brain Nerve 2016; 68:51-7.

71. Sackley C, Disler PB, Turner-Stokes L, Wade DT, Brittle N, Hoppitt T. Rehabilitation interventions for foot drop in neuromuscular disease. Cochrane Database SystRev 2009 Cd003908.

72. Kaya F, Belin S, Bourgeois P, Micaleff J, Blin O, Fontes M. Ascorbic acid inhibits PMP22 expression by reducing cAMP levels. Neuromusc Disord 2007;17:248-53.

73. Bordignon B, Mones S, Rahman F, et al. A derivative of ascorbic acid modulates cAMP production. Biochem Biophys Res Commun 2013;439:137-41.

74. Kaya F, Belin S, Diamantidis G, Fontes M. Ascorbic acid is a regulator of the intracellular cAMP concentration: old molecule, new functions? FEBS letters 2008;582:3614-8.

75. Ballaz SJ, Rebec GV. Neurobiology of vitamin C: Expanding the focus from antioxidant to endogenous neuromodulator. Pharmacol Res 2019;146:104321.

76. Passage E, Norreel JC, Noack-Fraissignes P, et al. Ascorbic acid treatment corrects the phenotype of a mouse model of Charcot-Marie-Tooth disease. Nat Med 2004;10:396-401.

77. Shy ME, Chen L, Swan ER, et al. Neuropathy progression in Charcot-Marie-Tooth disease type 1A. Neurology 2008;70: 378-83.

78. Micallef J, Attarian S, Dubourg O, et al. Effect of ascorbic acid in patients with Charcot-Marie-Tooth disease type 1A: a multicentre, randomised, double-blind, placebo-controlled trial Lancet Neurol 2009;8:1103-10.

79. Verhamme C, de Haan RJ, Vermeulen M, Baas F, de Visser M, van Schaik IN. Oral high dose ascorbic acid treatment for one year in young CMT1A patients: a randomised, double-blind, placebo-controlled phase II trial. BMC Med 2009; 7:70.

80. Pareyson D, Reilly MM, Schenone A, et al. Ascorbic acid in Charcot-Marie-Tooth disease type 1A (CMT-TRIAAL and CMT-TRAUK): a double-blind randomised trial. Lancet Neurol 2011;10:320-8.

81. Gess B, Lohmann C, Halfter H, Young P. Sodium-dependent vitamin C transporter 2 (SVCT2) is necessary for the uptake of L-ascorbic acid into Schwann cells. Glia 2010;58:287-99.

82. Gess B, Rohr D, Fledrich R, et al. Sodium-dependent vitamin C transporter 2 deficiency causes hypomyelination and extracellular matrix defects in the peripheral nervous system. J Neurosci 2011;31:17180-92.
83. Kaya F, Belin S, Diamantidis G, Fontes M. Ascorbic acid is a regulator of the intracellular cAMP concentration: old molecule, new functions? FEBS Lett 2008;582:3614-8.

84. Sereda MW, Meyer zuHorste G, Suter U, Uzma N, Nave KA. Therapeutic administration of progesterone antagonist in a model of Charcot-Marie-Tooth disease (CMT-1A). Nat Med 2003;9:1533-7.

85. Desarnaud F, Do Thi AN, Brown AM, et al. Progesterone stimulates the activity of the promoters of peripheral myelin protein-22 and protein zero genes in Schwann cells. JNeurochem 1998;71:1765-8.

86. Koenig HL, Schumacher M, Ferzaz B, et al. Progesterone synthesis and myelin formation by Schwann cells. Science (New York, NY) 1995;268:1500-3.

87. Cottu PH, Bonneterre J, Varga A, et al. Phase I study of onapristone, a type I antiprogestin, in female patients with previously treated recurrent or metastatic progesterone receptor-expressing cancers. PLoS One 2018;13:e0204973.

88. Klein-Hitpass L, Cato AC, Henderson D, Ryffel GU. Two types of antiprogestins identified by their differential action in transcriptionally active extracts from T47D cells. Nucleic Acids Res 1991;19:1227-34.

89. Meyer zuHorste G, Prukop T, Liebetanz D, Mobius W, Nave KA, Sereda MW. Antiprogesterone therapy uncouples axonal loss from demyelination in a transgenic rat model of CMT1A neuropathy. Ann Neurol 2007;61:61-72.

90. Robertson JF, Willsher PC, Winterbottom L, Blamey RW, Thorpe S. Onapristone, a progesterone receptor antagonist, as first-line therapy in primary breast cancer. Eur J Cancer (Oxford, England: 1990) 1999;35:214-8.

91. Liu N, Varma S, Tsao D, Shooter EM, Tolwani RJ. Depleting endogenous neurotrophin-3 enhances myelin formation in the Trembler-J mouse, a model of a peripheral neuropathy. J Neurosci Res 2007;85:2863-9.

92. Chao MV. Neurotrophins and their receptors: a convergence point for many signalling pathways. Nat Rev Neurosci 2003:4:299-309.

93. Sahenk Z, Ozes B. Gene therapy to promote regeneration in Charcot-Marie-Tooth disease. Brain Res 2020;1727:146533.

94. Lamballe F, Klein R, Barbacid M. trkC, a new member of the trk family of tyrosine protein kinases, is a receptor for neurotrophin-3. Cell 1991;66:967-79.

95. Sahenk Z, Galloway G, Clark KR, et al. AAV1.NT-3 gene therapy for charcot-marie-tooth neuropathy. Mol Ther 2014;22:511-21.

96. Sahenk Z, Nagaraja HN, McCracken BS, et al. NT-3 promotes nerve regeneration and sensory improvement in CMT1A mouse models and in patients. Neurology 2005;65:681-9.

97. Suter U, Moskow JJ, Welcher AA, et al. A leucine-to-proline mutation in the putative first transmembrane domain of the 22$\mathrm{kDa}$ peripheral myelin protein in the trembler-J mouse. Proc Natl Acad Sci U S A 1992;89:4382-6.

98. Liu S, Bohl D, Blanchard S, Bacci J, Said G, Heard JM. Combination of microsurgery and gene therapy for spinal dorsal root injury repair. Mol Ther 2009; 17:992-1002.

99. Wan H, Zhang L, Blanchard S, et al. Combination of hypoglossal-facial nerve surgical reconstruction and neurotrophin-3 gene therapy for facial palsy. J Neurosurg 2013;119:739-50.

100. Chumakov I, Milet A, Cholet N, et al. Polytherapy with a combination of three repurposed drugs (PXT3003) down-regulates Pmp22 over-expression and improves myelination, axonal and functional parameters in models of CMT1A neuropathy. Orphanet J Rare Dis 2014;9:201

101. Prukop T, Stenzel J, Wernick S, et al. Early short-term PXT3003 combinational therapy delays disease onset in a 
transgenic rat model of Charcot-Marie-Tooth disease 1A (CMT1A). PLoS One 2019;14:e209752.

102. Attarian S, Vallat JM, Magy L, et al. An exploratory randomised double-blind and placebo-controlled phase 2 study of a combination of baclofen, naltrexone and sorbitol (PXT3003) in patients with Charcot-Marie-Tooth disease type 1A. Orphanet J Rare Dis 2014;9:199.

103. Mandel J, Bertrand V, Lehert P, et al. A meta-analysis of randomized double-blind clinical trials in CMT1A to assess the change from baseline in CMTNS and ONLS scales after one year of treatment. Orphanet J Rare Dis 2015;10:74.

104. Chen Y, Podojil JR, Kunjamma RB, et al. Sephin1, which prolongs the integrated stress response, is a promising therapeutic for multiple sclerosis. Brain 2019;142:344-61.

105. Juneja M, Burns J, Saporta MA, Timmerman V. Challenges in modelling the Charcot-Marie-Tooth neuropathies for therapy development. J Neurol Neurosurg Psychiatry 2019;90:58-67.

106. Kannampalli P, Poli SM, Bolea C, Sengupta JN. Analgesic effect of ADX71441, a positive allosteric modulator (PAM) of GABAB receptor in a rat model of bladder pain. Neuropharmacology 2017;126:1-11.

107. Magnaghi V, Ballabio M, Camozzi F, et al. Altered peripheral myelination in mice lacking GABAB receptors. Mol Cell Neurosci 2008;37:599-609.

108. Butler JS, Chan A, Costelha S, et al. Preclinical evaluation of RNAi as a treatment for transthyretin-mediated amyloidosis. Amyloid 2016;23:109-18.

109. Adams D, Suhr OB, Dyck PJ, et al. Trial design and rationale for APOLLO, a Phase 3, placebo-controlled study of patisiran in patients with hereditary ATTR amyloidosis with polyneuropathy. BMC Neurol 2017;17:181.

110. Adams D, Gonzalez-Duarte A, O'Riordan WD, et al. Patisiran, an RNAi therapeutic, for hereditary transthyretin amyloidosis. N Engl J Med 2018;379:11-21.

111. Lee JS, Chang EH, Koo OJ, et al. Pmp22 mutant allele-specific siRNA alleviates demyelinating neuropathic phenotype in vivo. Neurobiol Dis 2017;100:99-107.

112. Bennett CF, Swayze EE. RNA targeting therapeutics: molecular mechanisms of antisense oligonucleotides as a therapeutic platform. Annu Rev PharmacolToxicol 2010;50:259-93.
113. Bennett CF. Therapeutic antisense oligonucleotides are coming of age. Annu Rev Med 2019;70:307-21.

114. Benson MD, Waddington-Cruz M, Berk JL, et al. Inotersentreatment for patients with hereditary transthyretin amyloidosis. N Engl J Med 2018;379:22-31.

115. Zhao HT, Damle S, Ikeda-Lee K, et al. PMP22 antisense oligonucleotides reverse Charcot-Marie-Tooth disease type 1A features in rodent models. J Clin Invest 2018;128:359-68.

116. Frazier KS. Antisense oligonucleotide therapies: the promise and the challenges from a toxicologic pathologist's perspective. ToxicolPathol 2015;43:78-89.

117. Caillaud M, El Madani M, Massaad-Massade L. Small interfering RNA from the lab discovery to patients' recovery. J Control Release 2020;321:616-28.

118. Bennett CF, Baker BF, Pham N, Swayze E, Geary RS. Pharmacology of antisense drugs. Annu Rev PharmacolToxicol 2017;57:81105.

119. Attarian S, Fatehi F, Rajabally YA, Pareyson D. Hereditary neuropathy with liability to pressure palsies. J Neurol 2020;267:2198-206.

120. Fortun J, Li J, Go J, Fenstermaker A, Fletcher BS, Notterpek L. Impaired proteasome activity and accumulation of ubiquitinated substrates in a hereditary neuropathy model. J Neurochem 2005;92:1531-41.

121. Kohl B, Fischer S, Groh J, Wessig C, Martini R. MCP-1/CCL2 modifies axon properties in a PMP22-overexpressing mouse model for Charcot-Marie-tooth 1A neuropathy. Am J Pathol 2010;176:1390-9.

122. Chittoor-Vinod VG, Lee S, Judge SM, Notterpek L. Inducible HSP70 is critical in preventing the aggregation and enhancing the processing of PMP22. ASN Neuro 2015;7:1759091415569909.

123. Zhu J, Chen W, Mi R, Zhou C, Reed N, Hoke A. Ethoxyquin prevents chemotherapy-induced neurotoxicity via Hsp90 modulation. Ann Neurol 2013;74:893-904.

124. Ekins S, Litterman NK, Arnold RJ, et al. A brief review of recent Charcot-Marie-Tooth research and priorities. F1000 Res 2015;4:53.

125. Schorling E, Thiele S, Gumbert L, et al. Cost of illness in Charcot-Marie-Tooth neuropathy: results from Germany. Neurology 2019;92:e2027-e37. 